\title{
THE DEVELOPMENT OF HAND SANITIZER (HS) PRODUCTION WITH SYNTHETIC AND NATURAL SCENT INGREDIENTS
}

\author{
Anugrah Ricky Wijaya, ${ }^{1 *}$ Irma Kartika Kusumaningrum ${ }^{1}$, Daratu Eviana Kusuma Putri ${ }^{1}$, \\ Bayu Kreshna Adhitya Sumarto ${ }^{2}$, Abdillah Al Farraby ${ }^{1}$, Yusron Risqy Maulana ${ }^{1}$, Puspa \\ Rahmadina Lestari ${ }^{1}$ \\ ${ }^{1}$ Chemistry Department, Universitas Negeri Malang (UM), Malang, Indonesia \\ ${ }^{2}$ Faculty of Science, University of The Ryukyus, Okinawa, Japan \\ ${ }^{2}$ The Indonesian student association in Okinawa, Japan
}

\begin{abstract}
The effort of developed hand sanitisers (HS) production is needed in the era of the Covid-19 pandemic. The improvement of HS in terms of colour, aroma sharpness, and hand comfort is very important in the consideration of users choosing the HS product used. The socialisation of this service aims to report community service in creating HS production on a scale of $6 \mathrm{~L} / 30$ minutes using Propeller Mixing Hand Sanitizer (PMHS) by testing color, aroma, and hand comfort using synthetic and natural materials with chemical technology processes. The addition of the aroma of natural ingredients from fruit, flowers or seeds using maceration techniques from strawberry fruit, jasmine flowers, green tea leaves, and coffee grounds were extracted by the natural aroma liquid, which were added to HS products. The addition of HS products with the aroma of natural ingredients from strawberry, jasmine, green tea, and coffee was compared to the synthetic aromas of strawberry, jasmine, green tea, and coffee obtained from perfume shops. The questionnaire test of 44 respondents consisting of lecturers, staff, administration, and students for HS products evaluated color, aroma sharpness, and hand comfort. The results show that the colour, sharpness of the aroma and a sense of comfort in the hands of HS products with synthetic aromas of jasmine and green tea are highly favoured by users. These results were recommended as a reference for the manufacture and distribution of HS aromas of jasmine and green tea on a large scale.
\end{abstract}

Keywords: Hand Sanitizer, Scent, Covid-19

\section{INTRODUCTION}

The types of microorganisms such as viruses, bacteria, and fungi contaminate the hands every day through physical contact with the environment and some of them can cause various diseases. These microorganisms were destroyed and prevented from spreading to the human body. One of the cheapest and most appropriate ways is to wash your hands with soap and clean running water. If clean water is not available, hand sanitiser containing alcohol or antibacterial can also be used as an alternative step known as hand sanitiser (HS).

HS is a liquid dosage product that is used without using water. This functional product gives a healthy and fresh scent on the hands and kill germs. This product is currently favoured by the public in order to maintain cleanliness and health during the COVID-19 pandemic. The hand is an intermediary medium for the spread of germs from inanimate objects or touch between humans. Some researchers classified the kind of two hand sanitisers, such as hand sanitiser gel and hand sanitiser spray (Aminah dkk., 2018; Golin, dkk., 2020). Hand sanitiser gel is a gel-shaped hand sanitiser that is useful for eliminating germs on hands and contains $60 \%$ alcohol as an active ingredient. HS spray is a hand sanitiser in the form of a spray to clean germs with an alcohol 
content of about $60 \%$. We decided to produce HS spray products because they are easier and more practical to manufacture and use.

The various scented hand sanitiser products that we have made are available in various variations. We produce HS with four variations of scent, such as strawberry, green tea, jasmine, and coffee because these scents are very popular with the public. Strawberry ingredients are famous for the fresh scent of the fruit which makes the hand sanitiser feel fresher. Green tea has a scent that can provide calm and comfort, so it is widely used as an option as an everyday perfume. Jasmine has a strong scent but still soft from the flowers and is suitable as a fragrance in HS production. Coffee, especially the coffee bean, it has a distinctive scent, durable, and widely used as scent therapy. The scent of the four variations could be obtained from natural or synthetic ingredients such as essential oils sold in the market. Here, we report users' interest in scent products from the four variants, such as strawberry, green tea, jasmine, and coffee using different extracts, collected from natural ingredients and synthesis of essential oils to increase efforts in hand sanitiser products.

\section{METHOD}

a.) HS Production using Propeller Mixing Hand Sanitizer (PMHS)

The PMHS tool was made in the Department of Chemistry to produce hand sanitisers with a capacity of $60 \mathrm{~L}$ for each production within 30 minutes. The PMHS tool is shown in the Figure 1, as follows:

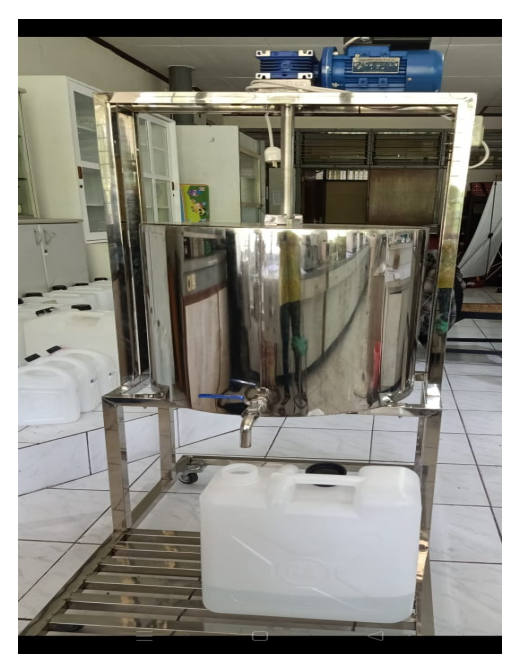

Figure 1. PMHS equipment for HS Production

Six liters of distilled water is included in the PMHS tool. 2.5 liters of 3\% $\mathrm{H} 2 \mathrm{O} 2$ solution was added to the PMHS slowly and carefully. $870 \mathrm{~mL}$ of $98 \%$ glycerol was then added to the mixture in PMHS. The PMHS device is turned on for 30 minutes. After finishing the mixing process for 30 minutes, the solution in PMHS was left for 3 days and put in a PMHS spray bottle (Anugrah dkk., 2020). The spray bottle containing PMHS will then be filled with artificial and natural synthetic scents for the next experiment.

\section{b.) Natural fragrance making and blending of HS Product}

Natural plant or fruit ingredients were chosen because they are comfortable and friendly to the skin, antibacterial, no use preservatives, easy to obtain and have a fresher scent than the synthetic ones. Extraction processes were performed by maceration for all natural ingredients (Nazma dkk., 2012). Strawberries were washed, cleaned and blended to release the strawberries filtrate. 28.35 grams of strawberries were put into a beaker and macerated with $700 \mathrm{~mL}$ of $96 \%$ ethanol for 24 hours and the filtrate was filtered and continued with concentration using a rotary 
evaporator at a temperature of 45 degrees Celsius. The filtrate was accommodated and used for the addition of HS scent. With the same procedure, $85 \mathrm{~g}$ of jasmine flower, $150 \mathrm{~g}$ of coffee, and 15 green tea were added according to the above procedure respectively to obtain the filtrate for the natural scent of jasmine, coffee, and green tea ingredients.

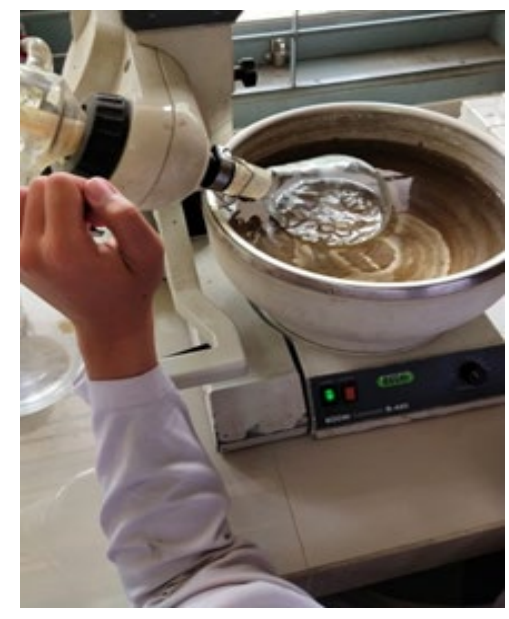

Figure 2. The equipment of Rotary Evaporator Process

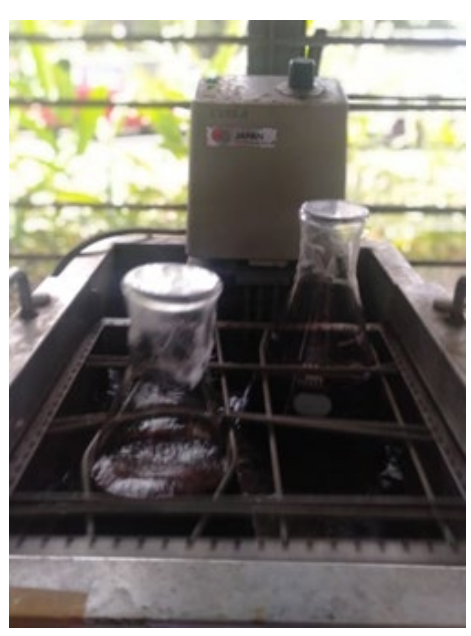

Figure 3. The equipment of Maceration Process

The process of mixing HS solution with scent is quite simple. $100 \mathrm{~mL}$ HS spray bottle, HS solution and desired ingredient were prepared together. $1 \mathrm{~mL}$ of scent coffee/green tea/strawberry/jasmine was put in a spray bottle. The mixture solution was then added $99 \mathrm{~mL}$ of HS solution into a spray bottle. The solution was then closed and gently shaken in the spray bottle for mixing with the ingredient. The results of the HS mixture were evaluated and compared with synthetic scents sold in the market.

\section{c.) Distribution of hand sanitiser quality questionnaires}

To find out the quality of the hand sanitiser, we conducted a trial on 44 respondents to try the HS that we made. There were eight HS with different scents, but respondents were not informed about the scent of the hand sanitiser. Instead, we labelled each HS according to the code number 1: synthetic strawberry; 2: natural strawberry; 3: jasmine synthesis; 4: natural jasmine; 5: synthetic green tea; 6: natural green tea; 7: synthetic coffee, and 8: natural coffee. After trying the HS product, respondents filled out the questionnaire that we gave. The questionnaire contains an assessment of HS in terms of color, scent and hand comfort. The questionnaire was made with the following levels: Strongly Dislike (SD), Dislike (D), Ordinary (O), Like (L), and Strongly Like (SL). 


\section{RESULT AND DISCUSSION}

\section{a.) Production of Hand Sanitizer (HS)}

HS is used to kill bacteria or germs on hands. HS spray is a liquid hand sanitiser that is sprayed to kill germs or bacteria on the hands. In this community service, the HS spray was chosen for maximum production of HS with PMHS tools at $60 \mathrm{~L} \mathrm{HS} / 30$ minutes. The Department of Chemistry has distributed around 1000 bottles of free HS with the synthetic scent of strawberry, jasmine, coffee, and green tea. In the development of HS making, HS socialisation was also carried out in online community service with the Chairman of the PPI Okinawa Japan for Tomarin fishermen who became the icon of the leading maritime village in Okinawa, Japan.

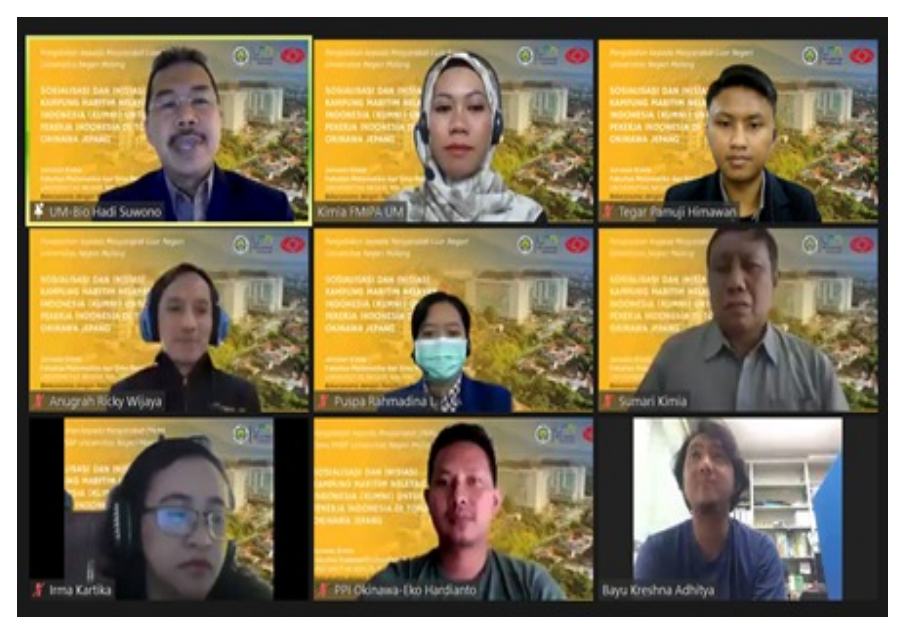

Figure 4. Socialisation of production HS with the head of PPI in Okinawa

For the development of the next production, the produced HS by the Department of Chemistry need suggestions and criticism for the development of HS production, it is necessary to distribute a questionnaire for comparison HS production between the flavoured natural and synthetic ingredients.

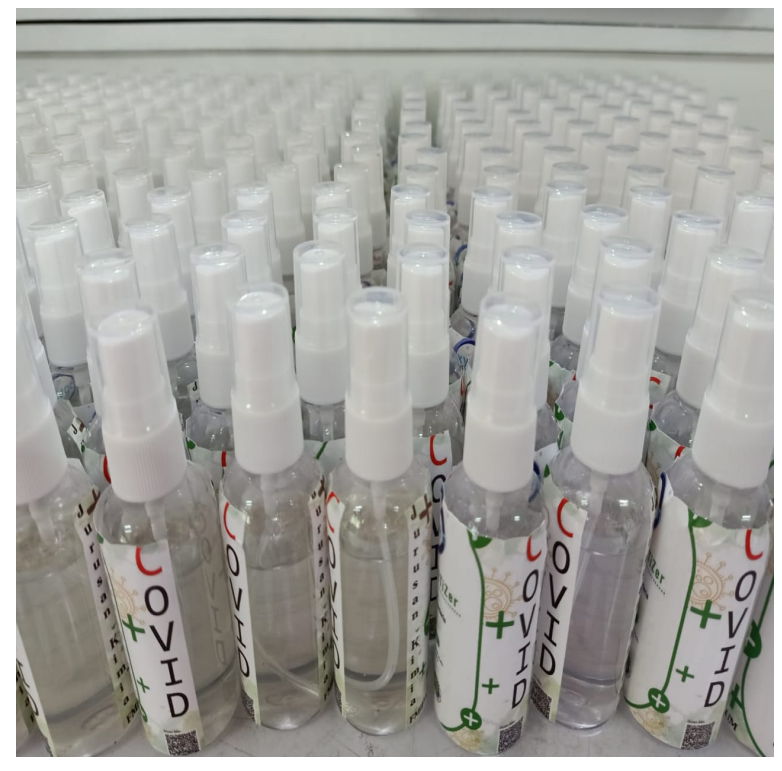

Figure 5. HS Products in the Chemistry Department, UM 


\section{b.) The result of natural ingredients HS production}

\section{Green Tea}

The green tea used in making the scent from the leaves of the tea plant (Camellia sinensis) was selected due to undergo a fermentation process. Green tea leaves are easy to dry and evaporate to get the scent out. The scent of green tea comes from the amino acid content in green tea which undergoes the breakdown of protein into amino acids. Amino acids together with carbohydrates and catechins will form scentsy compounds. The most influential amino acids in this regard are alanine, phenylalanine, valine, leucine, and isoleucine. (Riza dkk., 2018; Shabri dkk., 2016). The maceration process is the appropriate method used for the extraction of filtrate containing the scent of green tea.

\section{Coffee}

Two species of Robusta Coffee (Coffea canephora) and Arabica Coffee (Coffea arabica) were chosen as ingredients in the HS production of this coffee scent. This coffee was roasted and ground into powder to expand the surface of the coffee beans. The coffee sample was easily evaporated and macerated to release the scent. The scent of brewed coffee arises due to the evaporation of volatile compounds possessed by ground coffee, after it is brewed and caught by the human sense of smell (Diah dkk., 2018). Coffee beans naturally contain various types of volatile compounds such as aldehydes, furfurals, ketones, alcohols, esters, formic acid, and acetic acid which have volatile properties (Septiani dkk., 2020). These compounds are very important to be extracted by maceration for giving a strong scent of coffee in HS production.

\section{Strawberry}

The selected strawberries are fruits that can grow well on highland, because strawberries with a strong scent are technically influenced by a cold and humid environment. Strawberry fruit was collected from Batu city. The fruity scent of strawberries is caused by the content of volatile compounds or volatile compounds. Some researchers reported that the content of volatile compounds from the ester group increased the scent with the fruit ripens. Extraction using ethanol solvent by maceration process could increase the scent of strawberry in the HS production (Lutfi dkk., 2018).

\section{Jasmine}

Jasmine is taken from ornamental flower plants which has a distinctive scent and widely used as an ingredient for making perfumes. The scent of jasmine comes from the chemical compounds contained in jasmine flowers. Some researchers stated that the formation of jasmine scent comes from the structural compounds of the ketone groups cyclopentanones and cyclopentenones (Nazma dkk., 2012; Sulusi dkk., 2002). The structural elements in common are cyclopentanone or cyclopentenone rings with straight or branched chains of alkanes or alkene substituents. The scent of jasmine was extracted by maceration, which gave a concentrated scent of jasmine and bought a fresh scent to the HS product.

\section{c.) The questionnaire results of HS products from user satisfaction}

Table 1 reveals the number of comparisons of respondents in evaluating HS products in terms of colour, scent and hand comfort after adding synthetic or natural ingredients. The choice of respondents in terms of colour is more preferred HS products from synthetic materials compared to natural ones in the highest indicator (strongly like). The results of respondents who chose HS showed that the scent of green tea (15 person) and jasmine (14 person) were more highly preferred than the scent of strawberry and coffee with the addition of synthetic material.

Some of the respondents admitted that they stated to choose the colourless HS compared with the coloured HS. This can be seen from the results of the questionnaire which showed that 
HS with colour, namely HS labelled at no.4 (HS scent of natural jasmine), 6 (HS scent of natural green tea) and 8 (HS scent of natural coffee) had a mode in the normal, strong like and dislike. In addition, colourless HS (HS labelled 1, 2, 3, 5, 7) were in the normal to very favourable range.

Some respondents did not like the un colours HS product, other respondents admitted that they strongly like to choose the colours. This indicates that colour is the taste or subjectivity of each person. The colour from HS comes from natural extracts which are densely coloured, dark brown for coffee extract, dark green for green tea extract and pale yellow for jasmine extract. The mixture of extracts of natural ingredients makes the HS colour pale.

Table 1. The results of the HS interest questionnaire with various additional variables of synthetic and natural materials

\begin{tabular}{|c|c|c|c|c|}
\hline I & $\begin{array}{l}\text { Strawberry } \\
\text { Ingredient }\end{array}$ & Jasmine Ingredient & Green Tea Ingredient & Coffee Ingredient \\
\hline \multicolumn{5}{|c|}{ HS Colour } \\
\hline SD & $\begin{array}{l}\text { Synthetic }(0) \\
\text { Natural }(0)\end{array}$ & $\begin{array}{l}\text { Synthetic (0) } \\
\text { Natural (0) }\end{array}$ & $\begin{array}{l}\text { Synthetic (0) } \\
\text { Natural (1) }\end{array}$ & $\begin{array}{l}\text { Synthetic (0) } \\
\text { Natural (3) }\end{array}$ \\
\hline $\mathbf{D}$ & $\begin{array}{l}\text { Synthetic }(0) \\
\text { Natural }(0)\end{array}$ & $\begin{array}{l}\text { Synthetic (0) } \\
\text { Natural (5) }\end{array}$ & $\begin{array}{l}\text { Synthetic (0) } \\
\text { Natural (14) }\end{array}$ & $\begin{array}{l}\text { Synthetic (4) } \\
\text { Natural (11) }\end{array}$ \\
\hline $\mathbf{O}$ & $\begin{array}{l}\text { Synthetic (12) } \\
\text { Natural (13) }\end{array}$ & $\begin{array}{l}\text { Synthetic (10) } \\
\text { Natural (18) }\end{array}$ & $\begin{array}{l}\text { Synthetic (11) } \\
\text { Natural (14) }\end{array}$ & $\begin{array}{l}\text { Synthetic 11) } \\
\text { Natural (19) }\end{array}$ \\
\hline $\mathbf{L}$ & $\begin{array}{l}\text { Synthetic (21) } \\
\text { Natural (24) }\end{array}$ & $\begin{array}{l}\text { Synthetic (20) } \\
\text { Natural (17) }\end{array}$ & $\begin{array}{l}\text { Synthetic (18) } \\
\text { Natural (8) }\end{array}$ & $\begin{array}{l}\text { Synthetic (21) } \\
\text { Natural (7) }\end{array}$ \\
\hline VL & $\begin{array}{l}\text { Synthetic (11) } \\
\text { Natural (7) }\end{array}$ & $\begin{array}{l}\text { Synthetic (14) } \\
\text { Natural (4) }\end{array}$ & $\begin{array}{l}\text { Synthetic (15) } \\
\text { Natural (7) }\end{array}$ & $\begin{array}{l}\text { Synthetic (8) } \\
\text { Natural (5) }\end{array}$ \\
\hline \multicolumn{5}{|c|}{ HS Scent } \\
\hline SD & $\begin{array}{l}\text { Synthetic (0) } \\
\text { Natural (2) }\end{array}$ & $\begin{array}{l}\text { Synthetic (0) } \\
\text { Natural (2) }\end{array}$ & $\begin{array}{l}\text { Synthetic (0) } \\
\text { Natural (1) }\end{array}$ & $\begin{array}{l}\text { Synthetic (3) } \\
\text { Natural (2) }\end{array}$ \\
\hline D & $\begin{array}{l}\text { Synthetic (8) } \\
\text { Natural (10) }\end{array}$ & $\begin{array}{l}\text { Synthetic (3) } \\
\text { Natural (8) }\end{array}$ & $\begin{array}{l}\text { Synthetic (5) } \\
\text { Natural (12) }\end{array}$ & $\begin{array}{l}\text { Synthetic (8) } \\
\text { Natural (8) }\end{array}$ \\
\hline $\mathbf{O}$ & $\begin{array}{l}\text { Synthetic (6) } \\
\text { Natural (19) }\end{array}$ & $\begin{array}{l}\text { Synthetic (8) } \\
\text { Natural (21) }\end{array}$ & $\begin{array}{l}\text { Synthetic (8) } \\
\text { Natural (13) }\end{array}$ & $\begin{array}{l}\text { Synthetic (10) } \\
\text { Natural (17) }\end{array}$ \\
\hline $\mathbf{L}$ & $\begin{array}{l}\text { Synthetic (17) } \\
\text { Natural (8) }\end{array}$ & $\begin{array}{l}\text { Synthetic (12) } \\
\text { Natural (11) }\end{array}$ & $\begin{array}{l}\text { Synthetic (11) } \\
\text { Natural (14) }\end{array}$ & $\begin{array}{l}\text { Synthetic (12) } \\
\text { Natural (13) }\end{array}$ \\
\hline VL & $\begin{array}{l}\text { Synthetic (13) } \\
\text { Natural (5) }\end{array}$ & $\begin{array}{l}\text { Synthetic (21) } \\
\text { Natural (2) }\end{array}$ & $\begin{array}{l}\text { Synthetic (20) } \\
\text { Natural (2) }\end{array}$ & $\begin{array}{l}\text { Synthetic (11) } \\
\text { Natural (4) }\end{array}$ \\
\hline \multicolumn{5}{|c|}{ Hand comfort of $\mathrm{HS}$} \\
\hline SD & $\begin{array}{l}\text { Synthetic }(0) \\
\text { Natural }(0)\end{array}$ & $\begin{array}{l}\text { Synthetic (0) } \\
\text { Natural }(0)\end{array}$ & $\begin{array}{l}\text { Synthetic (0) } \\
\text { Natural (0) }\end{array}$ & $\begin{array}{l}\text { Synthetic (0) } \\
\text { Natural }(0)\end{array}$ \\
\hline D & $\begin{array}{l}\text { Synthetic (8) } \\
\text { Natural (1) }\end{array}$ & $\begin{array}{l}\text { Synthetic (0) } \\
\text { Natural ( } 7)\end{array}$ & $\begin{array}{l}\text { Synthetic (3) } \\
\text { Natural (4) }\end{array}$ & $\begin{array}{l}\text { Synthetic (2) } \\
\text { Natural (4) }\end{array}$ \\
\hline $\mathbf{O}$ & $\begin{array}{l}\text { Synthetic (5) } \\
\text { Natural (18) }\end{array}$ & $\begin{array}{l}\text { Synthetic (14) } \\
\text { Natural (10) }\end{array}$ & $\begin{array}{l}\text { Synthetic (7) } \\
\text { Natural (16) }\end{array}$ & $\begin{array}{l}\text { Synthetic (13) } \\
\text { Natural (14) }\end{array}$ \\
\hline $\mathbf{L}$ & $\begin{array}{l}\text { Synthetic (22) } \\
\text { Natural (15) }\end{array}$ & $\begin{array}{l}\text { Synthetic (17) } \\
\text { Natural (18) }\end{array}$ & $\begin{array}{l}\text { Synthetic (21) } \\
\text { Natural (17) }\end{array}$ & $\begin{array}{l}\text { Synthetic (18) } \\
\text { Natural (16) }\end{array}$ \\
\hline VL & $\begin{array}{l}\text { Synthetic (9) } \\
\text { Natural (10) }\end{array}$ & $\begin{array}{l}\text { Synthetic (13) } \\
\text { Natural (9) }\end{array}$ & $\begin{array}{l}\text { Synthetic (13) } \\
\text { Natural (7) }\end{array}$ & $\begin{array}{l}\text { Synthetic (10) } \\
\text { Natural (11) }\end{array}$ \\
\hline
\end{tabular}

The I indicate Indicator, SD (Strongly Dislike), D (Dislike), O (Ordinary),

L (Like), SL (Very Like), and (number) indicate the number of voters.

Table 1 states that respondents evaluated and assessed the scent in the hand after HS was sprayed on their hands. The results of respondents who chose HS showed that the scent of jasmine (21 people) and green tea (20 people) were more preferable to the scent of strawberry and coffee. Synthetic-scented HS is preferred over natural-scented HS. The results of the questionnaire showed that HS mixed with synthetic scent had a mode in the range of (L) likes and HS mixed with natural scent had a mode in the normal $(\mathrm{N})$ range. This is because the scent from HS has a 
natural smell which is not too sharp compared with synthetic scent. Scent HS made from natural ingredients is not sharp due to the fruit/leaf material containing volatile organic compounds more evaporating during the maceration process.

It is proven that many respondents cannot identify the HS scent from the scent of natural ingredients. Another factor is that scent was not detected, the ratio composition of adding scent to natural ingredients is only $1 \%$. Natural ingredients extract is only used in $1 \mathrm{ml}$ on $99 \mathrm{ml}$ of HS at every $100 \mathrm{ml} \mathrm{HS}$ production. The initial reason for the development of natural scent ingredients easily added to HS is that the ingredients can be found nearby.

Scent from HS made of synthetic ingredients is more strongly identified by respondents than natural ingredients. Synthetic ingredients can be found in perfume shops that have been mixed with high concentrations of alcohol compounds. At the time of the testimony, some respondents could immediately guess the scent of the HS product. However, several respondents admitted that the HS labeled 7 (scent coffee synthetic) had a very strong smell of coffee, which resulted in the results of the questionnaire receiving a dislike (D) of it. The level of hand comfort when HS was tested by spraying HS on the palms of the hands and felt by respondents is listed in Table 1 . The results of respondents who felt comfortable with their hands and categorised as very like (VL) of HS scents of jasmine and green tea were 13 more people than those who to choose the scents of strawberry and coffee.

Commonly our HS product was received by a response, they felt the sense of comfort in the hands of the respondents. All results of the questionnaire states that the majority of respondents like the comfort of all HS products. However, some respondents commented that after using HS, they felt hot in their skin on their hands. This depends on the different skin sensitivity of respondents to the HS products. Table 1 indicated the colour, scent and comfort of the HS products that are tried as references for considering and increasing HS production efforts which are generally accepted by the community.

Our Hand sanitiser production is easy to do and socialised to the public by teaching how to use and dilute the chemicals needed and the use of work safety to make this HS. The PMHS equipment made by our Chemistry Department is one example of the development of small industries to make HS easier and faster. This is also an experience that is socialised to the community to be able to create new jobs for the production of HS and then make products with interesting scent variations, causing this product to be of high value. In addition, to reduce the risk of producing HS is not comfortable, we encourage the public to be able to make HS according to WHO recommendations.

\section{CONCLUSION}

Scent HS can be obtained from extracts by natural and synthetic materials. The results obtained from the assessment show that synthetic scent HS is better in terms of color, aroma sharpness, and hand comfort compared to the scene of extracts from natural scent ingredients. The production of HS with synthetic jasmine and green tea is very popular with the respondents. In the future, the production of HS with synthetic jasmine and green tea should be increased for needing the public.

\section{ACKNOWLEDGMENT}

The author would like to thank the PNBP grant overseas in 2021 which has provided moral and financial support for this community service program.

\section{CONFLICT OF INTERESTS}

We declare there is no conflict of interest with this program of community service. 


\section{REFERENCES}

Kualitas Gel Pembersih Tangan (Handsanitizer) Dari Ekstrak Batang Pisang Dengan Penambahan Alkohol, Triklosan Dan Gliserin Yang Berbeda Dosisnya." Bioeksperimen 4(2):61-70.

Anugrah Ricky Wijaya, Yudhi Utomo, Sumari, and Irma Kartika Kusumaningrum. "Pembuatan Hand Sanitizer Menggunakan PMHS (Propeller Mixing Hand Sanitizer).”HKI: 2019

Diah JuliantariD, Ni Putu, Luh Putu Wrasiati, and Ni Made Wartini. 2018. "karakteristik ekstrak ampas kopi bubuk robusta (coffea canephora) pada perlakuan konsentrasi pelarut etanol dan suhu maserasi." Jurnal rekayasa dan manajemen agroindustri 6(3):243. doi: 10.24843/JRMA.2018.v06.i03.p08.

Golin, Andrew P., Dexter Choi, and Aziz Ghahary. 2020. "Hand Sanitisers: A Review of Ingredients, Mechanisms of Action, Modes of Delivery, and Efficacy against Coronaviruses." American Journal of Infection Control 48(9):1062-67. doi: 10.1016/j.ajic.2020.06.182.

Nazma Sabrina Sani, Rofiah Racchmawati dan Mahfud. 2012. "Pengambilan Minyak Atsiri Dari Melati Dengan Metode Enfleurasi Dan Ekstraksi Pelarut Menguap.” Jurnal Teknik Pomits 1(1):1-4.

Riza Ibnu Fajar, Luh Putu Wrasiati*, Lutfi Suhendra. 2018. "kandungan senyawa flavonoid dan aktivitas antioksidan ekstrak teh hijau pada perlakuan suhu awal dan lama penyeduhan." Jurnal Rekayasa Dan Manajemen Agroindustri 6(3):196-202.

Septiani Mangiwa, Agnes Eri Maryuni. 2020. "Pengaruh Metode Ekstraksi Terhadap Sifat Fisik Dan Kimia Ekstrak Biji Kopi Sangrai Jenis Arabika (Arabica Coffea) Asal Wamena Dan Lanny Jaya." AVOGADRO Jurnal Kimia 4(1):31-40.

Shabri dan Dadan Rohdiana. 2016. "Optimasi Dan Karakterisasi Ekstrak Polifenol Teh Hijau Dari Berbagai Pelarut.” Jurnal Penelitian Teh Dan Kina 19(1):57-66.

Sulusi Prabawati, Endang D. A., Suyanti, dan Dondy ASB. 2002. "Perbaikan Cara Ekstraksi Untuk MeningkatkanRendemen Dan Mutu Minyak Melati.” Jurnal Hortikultura 12(4):270-75. 